Supporting Information for

\title{
Green Fabrication of Bioactive Silver Nanoparticles Using Mentha Pulegium Extract under Alkaline: An Enhanced Anticancer Activity
}

\author{
Yinghui $\mathrm{Wang}^{a}$, and Simin Wei ${ }^{b, *}$ \\ ${ }^{a}$ College of Science, Chang'an University, Xi'an 710064, China; \\ ${ }^{b}$ State Key Laboratory of Research \& Development of Characteristic Qin Medicine Resources \\ (Cultivation), Co-Construction Collaborative Innovation Center for Chinese Medicine Resources \\ Industrialization by Shaanxi \& Education Ministry, Shaanxi University of Chinese Medicine, \\ Xianyang 712083, China \\ * Correspondence: weisimin@iccas.ac.cn
}




\section{Table of Contents}

Figure S1 The color of mixed solution at different $\mathrm{pH}$

Figure S2 Growth inhibitions assay created by AgNPs synthesized by Mentha pulegium

Table S1 Average size of synthesized AgNPs at different $\mathrm{pH}$ and incubation time

Table S2 Average size of biosynthesized AgNPs at different material ratio

Table S3 Polydispersity index of synthesized AgNPs at different $\mathrm{pH}$ and incubation time

Table S4 Polydispersity index of biosynthesized AgNPs at different material ratio

Table S5 Zeta potential of synthesized AgNPs at different $\mathrm{pH}$ 


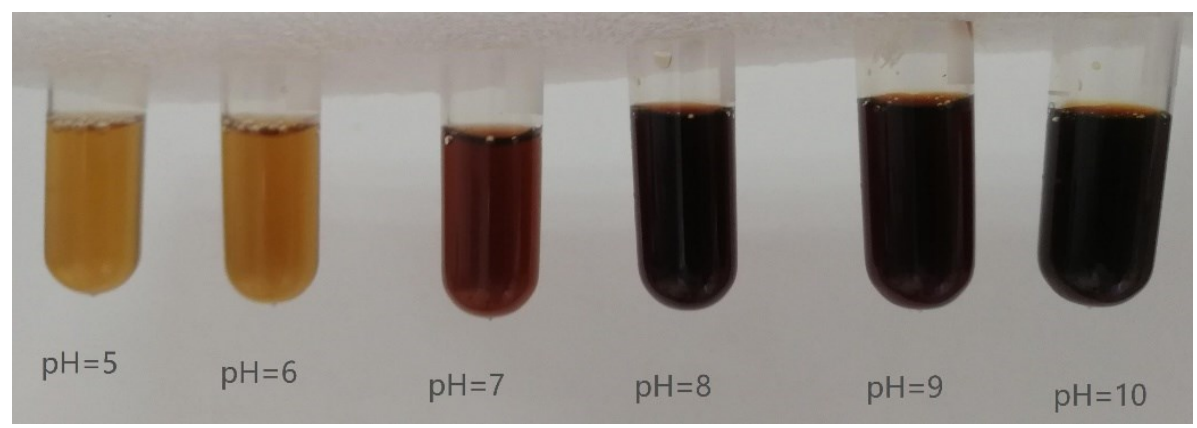

Figure S1 The photograph of mixed solution (5.0 mL Mentha pulegium extract and $5.0 \mathrm{~mL} 10 \mathrm{mM}$ $\mathrm{AgNO}_{3}$ ) at different $\mathrm{pH}$

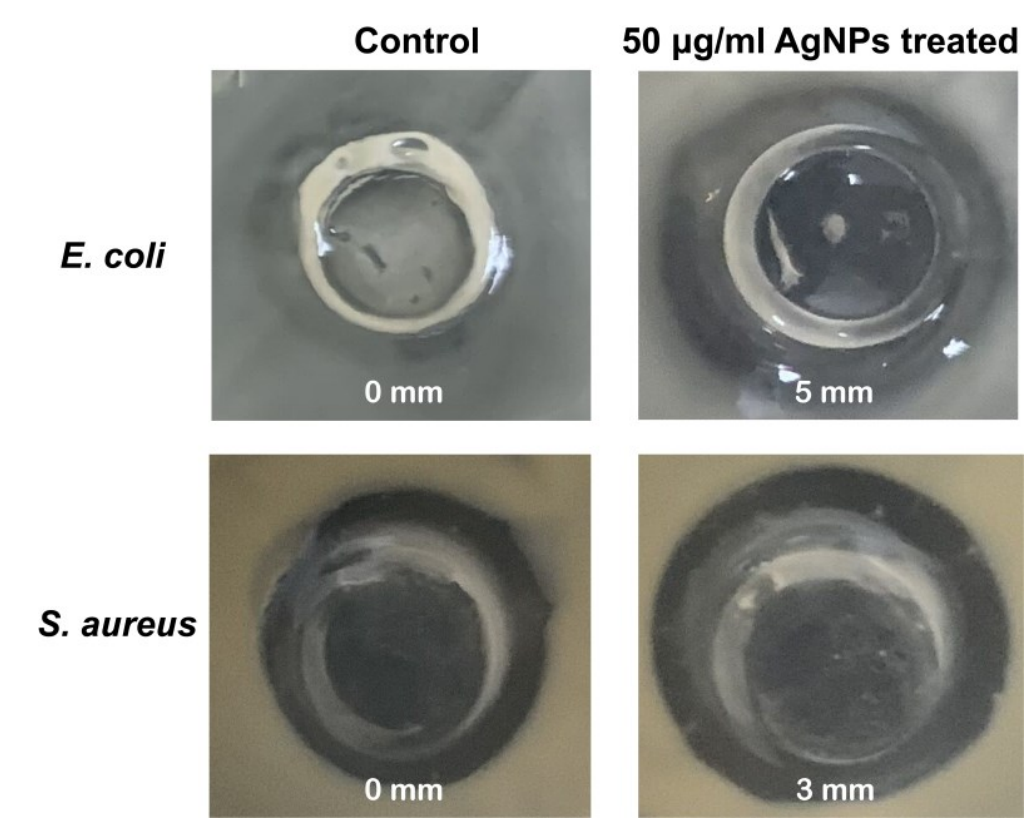

Figure S2 Growth inhibitions assay created by AgNPs biosynthesized by Mentha pulegium. The photographs were taken after incubation at $37^{\circ} \mathrm{C}$ overnight 
Table S1 Average size of biosynthesized AgNPs under different biosynthesis parameters $(5.0 \mathrm{~mL}$

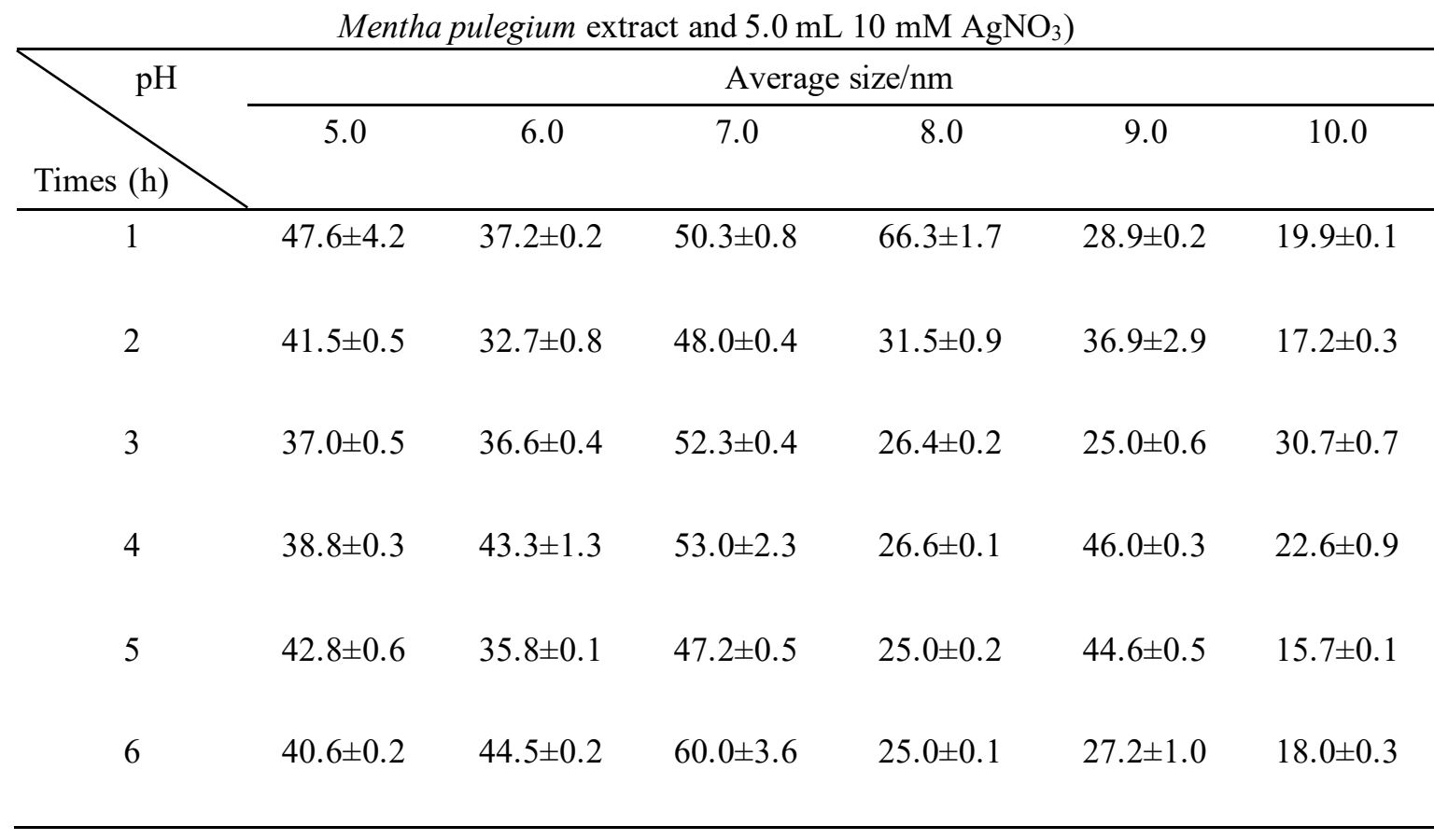

Table S2 Average size of biosynthesized AgNPs under different material ratio (at $\mathrm{pH} 10.0$ after incubation $4.0 \mathrm{~h}$ )

\begin{tabular}{cc}
\hline Extract: $\mathrm{AgNO}_{3}$ & Average size/nm \\
\hline $1: 1$ & $22.6 \pm 0.9$ \\
$1: 2$ & $44.8 \pm 0.3$ \\
$1: 3$ & $48.4 \pm 0.2$ \\
$1: 4$ & $55.0 \pm 0.5$ \\
$1: 5$ & $65.5 \pm 1.7$ \\
$1: 10$ & $60.0 \pm 0.8$ \\
$1: 20$ & $122.2 \pm 2.7$ \\
\hline
\end{tabular}

NOTE: the volume of $\mathrm{AgNO}_{3}(5.0 \mathrm{~mL})$ and mixed solution $(10.0 \mathrm{~mL})$ are kept in constant 
Table S3 Polydispersity index of synthesized AgNPs under different biosynthesis parameters (5.0 $\mathrm{mL}$ Mentha pulegium extract and $5.0 \mathrm{~mL} 10 \mathrm{mM} \mathrm{AgNO}_{3}$ )

\begin{tabular}{|c|c|c|c|c|c|c|}
\hline $\mathrm{pH}$ & & & Polydisper & index/PDI & & \\
\hline & 5.0 & 6.0 & 7.0 & 8.0 & 9.0 & 10.0 \\
\hline & & & & & & \\
\hline 1 & $0.46 \pm 0.13$ & $0.25 \pm 0.01$ & $0.43 \pm 0.02$ & $0.45 \pm 0.01$ & $0.30 \pm 0.01$ & $0.56 \pm 0.01$ \\
\hline 2 & $0.23 \pm 0.01$ & $0.36 \pm 0.06$ & $0.44 \pm 0.01$ & $0.50 \pm 0.01$ & $0.52 \pm 0.02$ & $0.57 \pm 0.01$ \\
\hline 3 & $0.45 \pm 0.01$ & $0.38 \pm 0.05$ & $0.39 \pm 0.01$ & $0.52 \pm 0.01$ & $0.58 \pm 0.01$ & $0.55 \pm 0.05$ \\
\hline 4 & $0.35 \pm 0.06$ & $0.41 \pm 0.02$ & $0.40 \pm 0.01$ & $0.55 \pm 0.01$ & $0.52 \pm 0.01$ & $0.59 \pm 0.04$ \\
\hline 5 & $0.28 \pm 0.01$ & $0.23 \pm 0.01$ & $0.24 \pm 0.01$ & $0.55 \pm 0.01$ & $0.53 \pm 0.01$ & $0.57 \pm 0.01$ \\
\hline 6 & $0.27 \pm 0.01$ & $0.28 \pm 0.01$ & $0.40 \pm 0.01$ & $0.55 \pm 0.01$ & $0.60 \pm 0.05$ & $0.64 \pm 0.01$ \\
\hline
\end{tabular}

Table S4 Polydispersity index of biosynthesized AgNPs under different material ratio (at $\mathrm{pH} 10.0$ after incubation $4.0 \mathrm{~h}$ )

\begin{tabular}{cc}
\hline Extract: $\mathrm{AgNO}_{3}$ & Polydispersity index/PDI \\
\hline $1: 1$ & $0.59 \pm 0.04$ \\
$1: 2$ & $0.25 \pm 0.01$ \\
$1: 3$ & $0.21 \pm 0.01$ \\
$1: 4$ & $0.26 \pm 0.01$ \\
$1: 5$ & $0.42 \pm 0.02$ \\
$1: 10$ & $0.29 \pm 0.01$ \\
$1: 20$ & $0.42 \pm 0.01$ \\
\hline
\end{tabular}

NOTE: the volume of $\mathrm{AgNO}_{3}(5.0 \mathrm{~mL})$ and mixed solution $(10.0 \mathrm{~mL})$ are kept in constant

Table S5 Zeta potential of synthesized AgNPs at different $\mathrm{pH}$ (Extract: $\mathrm{AgNO}_{3}=1: 1$, after $5.0 \mathrm{~h}$

\begin{tabular}{cc}
\multicolumn{2}{c}{ incubation) } \\
\hline $\mathrm{pH}$ & Zeta potential $/ \mathrm{mV}$ \\
\hline 5.0 & -14.73 \\
6.0 & -16.56 \\
7.0 & -15.93 \\
8.0 & -18.93 \\
9.0 & -22.83 \\
10.0 & -24.00 \\
\hline
\end{tabular}

